\title{
Articles
}

\section{The Principle of Mutual Recognition as a Utilitarian Solution, and the Way Forward}

\begin{abstract}
Anže Erbežnik ${ }^{\star}$
Abstract

The author is analysing the concept of mutual recognition as the "cornerstone" of mutual cooperation in criminal matters in the EU as regards its past development and experience with it, and the possible way forward. He addresses the issue of a proper equilibrium between the efficiency and prerogatives of law-enforcement agencies, on the one hand, and the rights of the accused, on the other, as mutual recognition is currently being applied in a framework of divergent national systems lacking a harmonised understanding and application of the basic principles of criminal procedure (outside the minimum framework of the ECHR). The area of freedom, security and justice is as such a non-finalised virtual reality of "checkerboard laws" and often functions on the basis of a utilitarian principle of trial and error, with some "collateral" problems regarding rights of the individual. Through a historical analysis of the U. S. system, it will be shown that such a situation has lead, at least in the U. S., to extensive and absolute harmonisation of certain basic principles of criminal procedure. According to the author, a similar development could occur in a distant future in the EU as well, whereby, for the time being, he proposes the application of mutual recognition based on the theory of composite constitutionalism.
\end{abstract}

\section{Introduction}

The aim of this article is to evaluate the principle of mutual recognition, as the so-called "cornerstone" of cooperation in criminal matters between EU Member States, from the perspective of the basic procedural rights of an individual in criminal procedure. The purpose of mutual recognition - after it was enshrined in the Treaties for the first time by the Treaty of Lisbon ${ }^{1}-$ is to preserve the national particularities of EU Member States in terms of criminal law, and at the same time

\footnotetext{
* Dr Anže Erbežnik, European Parliament, Committee on Civil Liberties, Justice and Home Affairs.

${ }^{1}$ Article 82(1) TFEU states explicitly that "judicial cooperation in criminal matters in the Union shall be based on the principle of mutual recognition and judicial decisions". This means that mutual recognition is now a Treaty principle. However, that Article is without prejudice to the application of the concept with due respect for "different legal systems and [constitutional] traditions of the Members States" (Article 67(1) TFEU). On the contrary, Articles 82 and 67(1) TFEU must be applied in a coherent way, thereby excluding automatic recognition in a non-harmonised system when two substantially different national systems clash with each other in terms of fundamental procedural rights within the framework of a national criminal procedure.
} 
to create a functioning, common legal space guaranteeing the free exchange and recognition of judicial measures. Such a characterisation (inherent also in Article 4 (2) TEU) could be considered as a paradox in itself, as, on the one hand, we admit that there are differences, and, on the other hand, a virtual common legal space is being created. ${ }^{2}$ Such a system can function smoothly if differences are minor and relate to certain technical rules, but it becomes difficult if considerable differences exist as regards the understanding and application of fundamental principles of criminal law. In the latter case, the functioning of such a system for a long period of time is theoretically and practically extremely problematic, as will be illustrated by the U.S. example. In this regard, it will be shown that a concept of mutual recognition not based on such a common understanding and application should be perceived as an intermediate utilitarian solution (with several "collateral problems" in terms of basic procedural rights) ${ }^{3}$, unable to function coherently in the long run without further comprehensive harmonisation of criminal procedures. The question is, of course, on which standards such harmonisation should be based - on the lowest, on the highest or on some middle point between the two? Therefore, mutual recognition could in the long run lead to substantial changes to fundamental constitutional traditions in criminal law in several Member States, due to the fact that criminal procedural rights are not only part of criminal procedural law, but also form part of the fundamental constitutional principles of the Member States. ${ }^{4}$ Such an evolution could happen due to the fact that no system can coherently apply two sets of fundamental constitutional rights, one for purely internal situations and another for cross-border cases, without becoming schizophrenic and losing its legitimacy in the eyes of the public.

\section{Functioning of mutual recognition}

The concept of mutual recognition was introduced by the 1999 Tampere European Council", based on the logic of the "country of origin principle" initially developed within the framework of the free movement of goods under the former first pillar (CJEU, 20. 2. 1979, case 120/78 (Rewe-Zentral AG/Bundes-

\footnotetext{
${ }^{2}$ For further reading on mutual recognition and its past and future perspective see also S. Peers, Mutual Recognition and Criminal Law in the EU: Has the Council Got it Wrong?, Common Market Law Review 2004, pp. 5-36; A. Weyembergh, "Approximation of Criminal Laws, The Constitutional Treaty and the Hague Programme", Common Market Law Review 2005, pp. 1576-1577; and Gisele Vernimmen-Van Tiggelen et al., The future of mutual recognition in criminal matters in the European Union, Universite de Bruxelles, 2009.

${ }^{3}$ This view was also expressed by Advocate General Ruiz-Jarabo Colomer in his opinion in the case C-297/07 (Klaus Bourquain), [2008] ECR I-9425, para. 41, to the effect that "mutual trust is a touch utilitarian when it supports the principle of mutual recognition".

${ }^{4} \mathrm{~V}$. Mitsilegas, The constitutional implications of mutual recognition in criminal matters in the EU, Common Market Law Review 2006, pp 1277-1311.

${ }_{5}^{5}$ The Tampere European Council conclusions, 15-16 October 1999, paras. 33-37, referred to mutual recognition as the "cornerstone of judicial co-operation in criminal matters", as well as to the abolishing of the classical extradition system, to pre-trial orders and admissibility of evidence as well as to harmonisation of procedural rules if necessary. See also the 2000 Programme of measures to implement the principle of mutual recognition of decisions in criminal matters (OJ C 12, 15. 1. 2001, p. 10), the 2004 The Hague Programme (OJ C 53, 3. 3. 2005, p. 1), and the 2009 Stockholm Programme (OJ C 115, 4. 5. 2010, p. 1).
} 
monopolverwaltung für Branntwein), [1979] ECR 649, the "Cassis de Dijon" case). ${ }^{6}$ However, what was overlooked was that decisions in a criminal procedure are not "goods" in the usual sense but relate to some fundamental constitutional principles as regards the rights of the individual. Mutual recognition was used under the former first pillar to enhance the four basic freedoms of individuals in the common market. However, the introduction of such a principle in the area of criminal law, without prior substantial harmonisation of defence rights, benefited mostly law-enforcement authorities, not defendants. There was also a democratic deficit at work. When adopted, mutual recognition was not scrutinized by a democratic legislator, but was a product of governmental effectiveness (Realpolitik). ${ }^{7}$ At the same time, the role of the European Parliament and national parliaments in the former third pillar was substantially curtailed or even nonexistent. $^{8}$ In the last ten years, mutual recognition became a kind of "self-fulfilling prophecy". It culminated in the adoption of the Lisbon Treaty, which entrenched the concept as a Treaty principle (see Article 82 TFEU), but without a prior analysis having been carried out to determine its nature and consequences. Nevertheless, a whole raft of far-reaching instruments based on mutual recognition has been adopted so far: Council Framework Decision 2002/584/JHA of 13 June 2002 on the European arrest warrant and the surrender procedures between Member States ${ }^{9}$, Council Framework Decision 2003/577/JHA on the execution in the EU of orders freezing property or evidence ${ }^{10}$, Council Framework Decision 2005/214/JHA on the application of the principle of mutual recognition for financial penalties ${ }^{11}$, Council Framework Decision 2006/783/JHA on the application of the principle of mutual recognition for confiscation orders ${ }^{12}$, Council Framework Decision 2008/909/JHA of 27 November 2008 on the application of the principle of mutual recognition for judgments imposing custodial sentences or measures involving deprivation of liberty ${ }^{13}$, Council Framework Decision 2008/947/JHA of 27 November 2008 on probation decisions and

${ }^{6}$ The "country of origin principle" is based on two rules: (a) presumption of mutual recognition of products being placed legally on the market; (b) "rule of reason" allowing certain limited grounds for refusal ("mandatory requirements"), such as fairness of commercial transactions, public health, protection of consumers, etc. An extension followed from the free movement of goods to the other freedoms (persons - CJEU, 15. 12. 1995, case C-415/93 (Bosman) [1995] ECR I-4921, and CJEU, 30. 11. 1995, case C-55/94 (Gebhard), [1995] ECR I-4165; services - CJEU, 25. 7. 1991, case C-76/90, (Säger/Dennemeyer), [1991] ECR I-4221; and capital - CJEU, 13. 5. 2003, case C-98/01, (Commission/United Kingdom), [2003] ECR I-4641).

T. Bunyan, The Story of Tampere, An undemocratic process excluding civil society, Statewatch, 2003, available at http://www.statewatch.org/news/2003/sep/tampere.pdf (last accessed 12 December 2011).

${ }^{8}$ Articles 34 and 39 of the former TEU limited the role of the European Parliament to the issuing of an opinion, and the 1997 Protocol on the role of national parliaments in the European Union provided only for an obligation to inform them on legislative proposals.

${ }^{9}$ OJ L 190, 18. 7. 2002, p. 1. See also Council Framework Decision 2009/299/JHA of 26 February 2009 amending Framework Decisions 2002/584/JHA, 2005/214/JHA, 2006/783/JHA, 2008/909/JHA and 2008/947/ JHA, thereby enhancing the procedural rights of persons and fostering the application of the principle of mutual recognition to decisions rendered in the absence of the person concerned at the trial (OJ L 81, 27. 3. 2009, p. 24).

${ }^{10}$ OJ L 196, 2. 8. 2003, p. 45.

${ }^{11}$ OJ L 76, 22. 3. 2005, p. 16.

${ }^{12}$ OJ L 328, 24. 11. 2006, p. 59

${ }^{13}$ OJ L 327, 5. 12. 2008, p. 27. 
alternative sanctions $^{14}$, Council Framework Decision 2008/978/JHA of 18 December 2008 on the European evidence warrant for the purpose of obtaining objects, documents and data for use in proceedings in criminal matters ${ }^{15}$, and Council Framework Decision 2009/829/JHA of 23 October 2009 on the application, between Member States of the European Union, of the principle of mutual recognition to decisions on supervision measures as an alternative to provisional detention ${ }^{16}$. Meanwhile, further instruments are planned, such as the proposed Directive on the European Investigation Order (EIO) in criminal matters ${ }^{17}$ providing for mutual recognition of almost all investigation measures. These instruments cover a variety of situations, from pre-trial measures, transfers of evidence, and transfers of suspects or convicted persons, to decisions based on a final court decision.

As it was assumed that national systems of EU Member States were already substantially coherent, only a limited number of grounds for non-recognition has been acknowledged $^{18}$, without there being specific grounds for non-recognition based on violations of human rights or of fundamental national constitutional principles and with only a broadly worded reference to fundamental rights ${ }^{19}$. As the instruments were adopted in the form of framework decisions, without direct effect and without there being a possibility of starting infringement proceedings, there were considerable differences between Member States in terms of transposition (for example, some included special grounds in their national law for non-recognition on the basis of a "human rights violation") ${ }^{20}$ and several national courts chose a specific application of some of the instruments in conformity with their national constitutions. ${ }^{21}$ At the same time, an important question in judicial cooperation in criminal matters concerns the definition of "judicial authorities", as such a definition has been left in some of the mutual recognition instruments to the discretion of individual Member States, resulting in a wide variety of authorities being named

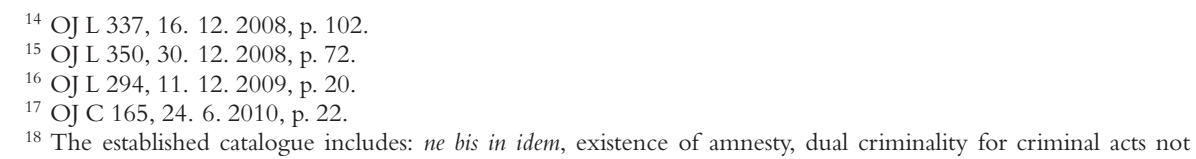
covered by the 32 categories excluding a check, territoriality principle, existence of immunity or privilege, and national security.

${ }^{19}$ Usually, with a recital referring to Article 6 TEU and the Charter, with a specific text on the prohibition of discrimination, and stating in an Article that "this Framework Decision shall not have the effect of modifying the obligation to respect fundamental rights and fundamental legal principles as enshrined in Article 6 of the Treaty on European Union". An exemption to this presents Framework Decision 2005/214/JHA on financial penalties stating (Article 20(3)): "Each Member State may, where the certificate referred to in Article 4 gives rise to an issue that fundamental rights or fundamental legal principles as enshrined in Article 6 of the Treaty may have been infringed, oppose the recognition and the execution of decisions."

${ }^{20}$ See, for example, Section 21 of the UK Extradition Act 2003 (c. 41), referring to a violation on human rights grounds, or Section 37 of the Irish European Arrest Warrant Act 2003 (n. 45) referring to a violation of the ECHR or the national constitution.

${ }^{21}$ See BVerfGE 113, 273, Judgment of 18 July 2005 ("European Arrest Warrant Act case"), demanding specific provisions as regards the protection of German citizens; Supreme Court of Cyprus, Attorney General of the Republic v. Konstantinou, No. 294/2005, Judgment of 7 November 2005; Polish Constitutional Court, P 1/05, Judgment of 27 April 2005. 
"judicial" - ranging from genuine judges, to prosecutors and even to police/administrative authorities. ${ }^{22}$ Furthermore, the practical application of the European Arrest Warrant (EAW) as the first mutual recognition instrument adopted in EU criminal law revealed some problems. ${ }^{23}$ The following questions emerged in connection with the EAW: a strict application of the legality principle in some Member States which issued an EAW for minor cases and the issue of proportionality ${ }^{24}$, prison conditions $^{25}$, the question of dual criminality ${ }^{26}$, and the definition of judicial authorities $^{27}$.

\section{The myth of a full consistency between the criminal procedures of the EU Member States}

The principle of mutual recognition rests on the assumption that EU Member States understand and apply fundamental principles of criminal procedure in the same way, since they are all signatories to the European Convention for the Protection of Human Rights and Fundamental Freedoms (ECHR). That initial

\footnotetext{
22 Article 6 of Framework Decision 2002/584/JHA on the EAW, Article 2(a) of Framework Decision 2003/577/ JHA on freezing, and Articles 2(c) and 3 of Framework Decision 2008/978/JHA on the EEW. However, there should be a differentiation between judicial and police cooperation, as the Treaty legal basis for both types of cooperation is different (and the German version of Article 82(1) TFEU implies an even more restricted meaning of "judicial" by referring only to "court" judgments and decisions - "gerichtliche Urteile und Entscheidungen"). In this regard, Framework Decision 2008/978/JHA (EEW) already introduced a validation procedure when a-typical "judicial" authorities were involved in the issuing of the EEW- see Recital 9 and Article 11(4) and (5), a solution followed by the Council in the framework of the proposed EIO. A validation procedure has been also recommended by the EU Agency for Fundamental Rights (FRA) in its opinion of 14 February 2011 on the proposed EIO directive, available at http://fra. europa.eu/fraWebsite/attachments/FRA-Opinion-EIO-Directive-15022011.pdf (last accessed 9 December 2011), p. 12: "The existing jurisprudence of the ECtHR does not generally require prior judicial authorisation for the use of most intrusive investigatory measures; cross-border investigations are different with respect to the interaction of two possibly incompatible legal systems. As such investigations often give rise to fundamental rights concerns, and therefore it may be necessary to require mandatory validation by a judge in the issuing state rather than a prosecutor or investigating magistrate. Specific procedures should be put in place for such a validation in order to avoid unnecessary delays." Such a procedure has been proposed in the draft report of the European Parliament of 16 December 2011 (PE478.493) demanding a validation of police requests (Amendments 7 and 22) and providing the possibility of non-recognition if "the measure has not been validated by a judge in a case where, in the issuing State, the measure has not been issued by a judge, but this requirement exists in the executing State" (Amendment 41).

${ }^{23}$ O. Pollicino, European Arrest Warrant and Constitutional Principles of the Member States: a Case Law-Based Outline in the Attempt to strike the Right Balance between Interacting Legal Systems, German Law Journal 2008, pp. 1313-1355; see also A. Górski, P. Hofmanski, The European Arrest Warrant and its Implementation in the Member States of the European Union, 2008, available at http://www.law.uj. edu.pl/ kpk/eaw/other/220_EAW. pdf (last accessed 23 December 2011); as well as the latest 2011 Commission report on the implementation since 2007 of the Council Framework Decision of 13 June 2002 on the European arrest warrant and the surrender procedures between Member States (COM(2011)175.

${ }^{24}$ Council conclusions on follow up to the recommendations in the final report on the fourth round of mutual evaluations concerning the European arrest warrant and surrender procedures among the member states of the EU, 3 June 2010, available at http://www.consilium.europa.eu/uedocs/cms_Data/docs/pressdata/en/jha/114859.pdf (last accessed 23 December 2011); see also OLG Stuttgart, 1 Ausl. (24) 1246/2009, Judgment of 25 February 2010, using Article 49(3) of the Charter to read a proportionality requirement into national legislation on the EAW.

${ }^{25}$ See, for example, the decision of the Irish Supreme Court in the case MJELR v. Rettinger, [2010] IESC 45, Judgment of 23 July 2010, clarifying that national judges are bound by the ECtHR when applying national legislation transposing EU legal instruments (EAW); and the decision of the ECtHR in the case Orchowski v. Poland, Application no. 17885/04, Judgment of 22 October 2009, on overcrowding in Polish prisons.

${ }^{26}$ See the Assange case - High Court of Justice, case CO/1925/2011, paras. 55-127.

${ }^{27}$ Ibid., paras. 20-54.
} 
perception was due to an oversimplification of the system of criminal procedure and overlooked the fact that the ECHR and the case-law of the European Court of Human Rights (ECtHR) only lay down minimum standards, without explicitly clarifying some essential questions. Thus the ECHR and the ECtHR case-law do not provide any clear theory on the admissibility of evidence and the exclusionary rule, nor do they give any clear indication of an effective way (through a kind of "Miranda warnings") to protect the privilege against self-incrimination. ${ }^{28}$ At the same time, they provide only basic safeguards against invasions of privacy under Article 8 ECHR, not always requiring a court authorisation for certain measures. A mere ten years after the introduction of the principle of mutual recognition, substantial research as well as the judgments of the ECtHR brought to light flaws in the protection of fundamental rights in several EU Member States. For example, several Member States did not properly inform the suspects of their rights ${ }^{29}$, France had to change its system of pre-trial interrogation and detention ${ }^{30}$, the Polish prison system has been declared to be systematically overcrowded in violation of Article 3 $\mathrm{ECHR}^{31}$, in Finland the police by itself (without any prior or post judicial scrutiny) could order a house search in violation of Article $8 \mathrm{ECHR}^{32}$, etc. The findings of the 2009 research, financed by the Commission, were also astonishing, stating that "fundamental rights such as the right to remain silent, to have access to the file and to call/or examine witnesses or experts, that are basic requirements of a fair trial in the ECHR are not provided for in the legislation of all Member States", and underlining the "need for EU action". 33 Therefore, any presumption of full consistency between criminal procedures in different EU Member States is based on a myth, leading to a situation where the common Area of Freedom, Security and Justice is under construction, and is still to some extent a "checker-board" area of disparate laws.

\footnotetext{
${ }^{28}$ The privilege against self-incrimination is not directly mentioned in Article 6 ECHR. Nonetheless, the ECtHR reads it into the meaning of a fair trial - Saunders v. UK, Application no. 19187/91, Judgment of 17 December 1996, p. 68 ("The Court recalls that, although not specifically mentioned in Article 6 of the Convention, the right to silence and the right not to incriminate oneself, are generally recognised international standards which lie at the heart of the notion of a fair procedure under Article 6. Their rationale lies, inter alia, in the protection of the accused against improper compulsion by the authorities thereby contributing to the avoidance of miscarriages of justice and to the fulfilment of the aims of Article.").

${ }^{29}$ T. Spronken, G. Vermeulen, D. de Vocht and L. van Puyenbroeck, EU Procedural Rights in Criminal Proceedings, Institute for International Research on Criminal Policy, Ghent University, 2009, accessible at www.eulita.eu/euprocedural-rights-criminal-proceedings (last accessed on 12 December 2011). The study showed a divergency as regards initial giving of warnings and the right to a lawyer before and during initial pre-trial interrogations, posing questions about conformity of such practices with the principle the ECtHR established in the case Salduz v. Turkey, Application no. 36391/02, Judgment of 27 November 2008, stating that (para. 55) "Article 6\$1 requires that, as a rule, access to a lawyer should be provided as from the first interrogation of a suspect by the police, unless it is demonstrated in the light of the particular circumstances of each case that there are compelling reasons to restrict this right... The rights of the defence will in principle be irretrievably prejudiced when incriminating statements made during police interrogation without access to a lawyer are used for a conviction".

${ }^{30}$ ECtHR, Moulin v. France, Application no. 37104/06, Judgment of 23 November 2010, and Brusco v. France, Application no. 1466/07, Judgment of 14 October 2010.

${ }^{31}$ ECtHR, Orchowski v. Poland, Application no. 17885/04, Judgment of 22 October 2009.

32 ECtHR, Heino v. Finland, Application no. 56720/09, Judgment of 15 February 2011, and Harju v. Finland, Application no. 56719/09, Judgment of 15 February 2011.

33 Spronken et al. (fn. 29), p. 122.
} 


\section{IV. 'Checkerboard laws' and the U. S. experience}

The U.S. provides an interesting example of an extreme application of mutual recognition to basic constitutional rights as regards the understanding and application of the federal Bill of Rights ${ }^{34}$, limited at first to application at the federal level alone. ${ }^{35}$ In the U.S. system, mutual recognition of extremely different and contradictory viewpoints on fundamental rights reached its peak in relation to slavery. ${ }^{36}$ Before the Civil War, there was an attempt to combine two kinds of opposite systems, allowing and prohibiting slavery at the same time within the framework of a single nation. The legal difficulty in accommodating such divergent systems culminated in the U.S. Supreme Court case of Dred Scott v. Sandford, 60 U. S. 393 $(1856)^{37}$, a couple of years before the beginning of the Civil War, where the Court has been confronted with the question of liberating a slave living for extensive periods of time with his owner in a non-slave territory. Thereby, the Court annulled the so-called Missouri compromise ${ }^{38}$ by seven votes to two, and proclaimed that no African American, even a free one, can become a fully fledged U.S. citizen ${ }^{39}$, applying at the same time the mutual recognition theory to slaves as being considered to be property (according to the 5th Amendment) and to the free circulation of such "property" all over the territory of the United States. Such a decision terminated any hopes for a gradual and peaceful abolition of slavery, as it was still envisaged in the time of the Framers, and led to the adjustment of the system to the lowest common denominator. The mentioned judgment took the mutual recognition principle to its extreme, showing the problem of mutual recognition in asymmetric conditions as regards the protection of human rights. Dworkin named such a system checkerboard laws as an attempt to apply inside the same legal area opposite viewpoints. ${ }^{40}$ After the Civil War, as a consequence of the failed attempt of mutual recognition, several additional amendments were adopted under the federal Bill of Rights (the 13th, 14th and 15th Amendment). The application of the 14th Amendment even lead in the long run to substantial harmonisation of certain

\footnotetext{
${ }^{34}$ A. R. Amar, The Bill of Rights, Yale University Press, 1998.

${ }^{35}$ The situation has been similar to the current status of the EU Charter of Fundamental Rights.

${ }^{36}$ Of course, the given U.S. example should be understood only as an illustration of the application of mutual recognition in its extreme on something as fundamentally wrong as slavery, and can in no way be directly compared with the situation in EU criminal law, where common fundamental principles do exist but are perhaps interpreted differently.

${ }^{37}$ Dred Scott was a slave accompanying his owner from Missouri (a slave state) first to Illinois (a non-slave state) and then to Fort Snelling, which was located in an area north of the geographical parallel defined by the federal legislature as the border of slave states. Upon returning to Missouri, Dred Scott started proceedings to win his freedom and that of his family on the ground that he had been living for several years in a territory where slavery was prohibited. He won in the first instance, but the Missouri Supreme Court overturned that decision. Further proceedings had been adjourned as proceedings had been launched in federal courts due to the fact that the caretaker of the property after the death of the original owner was a national of the State of New York, and culminated with the decision of the U.S. Supreme Court.

38 The 'Missouri Compromise' was federal U.S. legislation from 1820 on an agreement between the pro-slavery and anti-slavery factions as regards the question of slavery in the new western territories. Slavery was prohibited north from the parallel of 36 in 30', with the exception of the state of Missouri.

${ }^{39}$ It justified its decision by referring to the original setting when the constitution has been adopted.

${ }^{40}$ R. Dworkin, Law's Empire, Harvard University Press, 2001, str. 179-186.
} 
basic principles from the Bill of Rights (the application of the federal Bill of Rights in internal matters of the federal states $-1^{\text {st }}, 2^{\text {nd }}, 4^{\text {th }}, 5^{\text {th }}$ (without the grand jury clause), $6^{\text {th }}$ and $8^{\text {th }}$ Amendment (on cruel and unusual punishment)), including the ones relating to criminal procedure. ${ }^{41}$ This was a consequence of the experience that mutual recognition can only function if basic constitutional principles are understood and applied in the same way.

\section{EU harmonisation attempts}

The Stockholm programme ${ }^{42}$, as well as the subsequent Commission Action Plan ${ }^{43}$, were both adopted in parallel with the entry into force of the Lisbon Treaty, and explicitly acknowledged the absence of a proper equilibrium in the past caused by mutual recognition - to the benefit of law-enforcement efficiency and to the detriment of defence rights. ${ }^{44}$ To remedy the situation, in 2009 , the Council adopted the so-called "Roadmap" - a variety of measures to be adopted for harmonising criminal procedural rights in the EU. ${ }^{45}$ This concerned the following rights: (a) translation and interpretation, (b) information on rights and information about charges, (c) legal advice and legal aid ${ }^{46}$, (d) communication with relatives, employers and consular authorities, (e) special safeguards for vulnerable groups, and (f) pre-trial detention. Measure (a) has already been adopted ${ }^{47}$ in the form of a directive enhancing the existing obligations under Article $6 \mathrm{ECHR}$ on providing interpretation and translation in a criminal procedure. ${ }^{48}$ Measure (b) on information in criminal proceedings - introducing a kind of "EU Miranda warnings" - has been agreed as well. ${ }^{49}$ Yet even the adoption of the two aforementioned measures and of possible further "Roadmap" measures (such as access to a lawyer) would not solve all the problems as regards mutual recognition. On the one hand, the Commission did not elaborate on the central role of the privilege against self-incrimination in a

\footnotetext{
${ }^{41}$ See, for example U.S. Supreme Court, Gitlow v. New York, 268 U.S. 652 (1925), starting with the incorporation.

42 OJ C 115, 4. 5. 2010, p. 1.

${ }^{43} \operatorname{COM}(2010) 0171$.

${ }^{44}$ See also C. Rijken, Re-balancing security and justice: protection of fundamental rights in police and judicial cooperation in criminal matters, Common Market Law Review 2010, pp. 1455-1492.

${ }^{45}$ Resolution of the Council of 30 November 2009 on a Roadmap for strengthening procedural rights of suspected or accused persons in criminal proceedings (OJ 2009 C 295, 4. 12. 2009, p. 1).

${ }^{46}$ Proposal for a Directive of the European Parliament and of the Council on the right of access to a lawyer in criminal proceedings and on the right to communicate upon arrest (COM(2011)326).

${ }^{47}$ Directive 2010/64/EU of the European Parliament and of the Council of 20 October 2010 on the right to interpretation and translation in criminal proceedings (OJ L 280, 26. 10. 2010, p. 1).

${ }^{48}$ Such rights are being triggered when the procedure comes in front of a criminal court, in discrepancy with the proposed EIO directive where, according to Article 4(b), a request could be made even in proceedings brought by administrative authorities through which the decision may give rise to proceedings before a court having jurisdiction in particular in criminal matters. Such use of MLA formulas is unduly extending mutual recognition in criminal matters to administrative authorities, whereby in administrative procedures the safeguards are usually less extensive and the required amount of evidence for establishing one's wrongdoing much lower.

${ }^{49}$ Proposal for a Directive of the European Parliament and Council on the right to information in criminal proceedings (COM(2010)392). Agreed version of the text available at http://www.europarl.europa.eu/sides/getDoc. do?type $=$ TA\&language $=$ EN\&reference $=$ P7-TA-2011-0551 (last accessed 22 December 2011).
} 
criminal procedure. For example, the agreed Directive on information in criminal proceedings did not in its original Commission version include a warning as regards the right of the suspect to remain silent (as known from the famous Miranda case). ${ }^{50}$ On the other hand, there is no common understanding of the role of a prosecutor in the criminal proceedings (the main question being if a prosecutor could be perceived as a quasi-court authority, as this is the case in several Member States) and his/her prerogatives to authorise certain measures intruding into privacy (for example, house searches). Furthermore, a common understanding of the exclusionary rule is missing at EU level, whereby it is not clear what would happen if the new EU rules on harmonising criminal procedures were not to be followed. Would this be grounds for non-recognition within mutual recognition? Thus, even if the introduction of the "Roadmap" measures is remedying the situation to an important extent, it does not address some other important topics of criminal procedural law, such as admissibility of evidence ${ }^{51}$ (as regards possible infringements of the privilege against self-incrimination, and the right to privacy) and the existence of stricter national constitutional standards.

\section{The exclusionary rule}

The exclusionary rule refers to the elimination of illegal evidence from the criminal procedure. As such, it is intended to remedy illegal behaviour of state authorities when obtaining evidence. The exclusionary rule was/is not perceived as the only possible remedy against illegal police behaviour. Disciplinary or criminal proceedings against officers or damage claims were often considered as an alternative. ${ }^{52}$ A full theory of the exclusionary rule has been developed in the U.S. as regards the privilege against self-incrimination (5th Amendment) and in relation to illegal searches and seizures (4th Amendment). Any violation of the 5th Amendment's privilege against self-incrimination triggers the exclusionary rule, and the U.S. Supreme Court introduced a judge-made system of prior warnings (Miranda warnings) for and effective protection of this privilege. ${ }^{53}$ On the other hand, the exclusionary rule for any violation of the 4th Amendment is based on a utilitarian deliberation about the preventive effect on future police behaviour. ${ }^{54}$ At the same

\footnotetext{
${ }^{50}$ It was only through the insistence of the European Parliament that such a right has been introduced, albeit as the last of the enumerated warnings, thereby not following the order as stemming from the original Miranda system (Article 3 of the agreed text).

${ }^{51}$ Whereby Article 82(2) TFEU allows for minimum rules to be established for mutual admissibility of evidence.

${ }^{52}$ B. M. Zupančič, The Owl of Minerva, Eleven 2008, pp. 125-146.

${ }^{53}$ U.S. Supreme Court, Miranda v. Arizona, 384 U.S. 436 (1966). It is necessary to differentiate between the privilege against self-incrimination as a constitutional right and the Miranda warnings as a prophylactic rule to protect this constitutional right. Therefore, any violation of the Miranda warnings (although this is the presumption) does not amount to a violation of the privilege, and several exceptions were developed as regards a violation of the Miranda warning system.

${ }^{54}$ R. B. Bloom, Searches, Seizures and Warrants, Praeger, 2003; see also U.S. Supreme Court case-law: Mapp v. Ohio, 367 U.S. 643 (1961), extending the exclusionary rule as regards a 4th Amendment violation to the federal states (compare with Wolf v. Colorado, 338 U.S. 25 (1949), where the Court still refused to impose the exclusionary rule on the federal states); United States v. Calandra, 414 U.S. 338 (1974), introducing the so-called balancing test;
} 
time the "fruit of the poisonous tree doctrine" with several exemptions has been developed. ${ }^{55}$ Such concepts have been extended from the federal level to individual federal states, based on the incorporation of the Bill of Rights to individual federal states through an application of the 14th Amendment. ${ }^{56}$

In the EU a common system of the exclusionary rule is missing. Member States have their own systems, ranging from no exclusionary rule to a fully-fledged exclusionary rule. Recently, at least in the framework of the ECHR system, some kind of an exclusionary theory has been developed as regards a violation of Article 3 ECHR on torture, inhuman and degrading treatment. In the case of Gäfgen v. Germany, Application no. 22978/05, judgments of 30 June 2008 and 1 June 2010, German courts admitted real evidence obtained as a consequence of an initial threat of force by the police, whereby the accused, after being convicted, claimed that his decision to testify had been a consequence of the initial illegal behaviour of the police and the real evidence stemming from it and admitted to the file. The ECtHR deliberated twice on the case (7-Member chamber and the Grand Chamber) developing the following theory as regards the interplay between Articles 3 and 6 ECHR: - all statements gathered directly by a violation of Article 3 ECHR have to be excluded; - real evidence stemming directly from a violation of Article 3 (see Jalloh v. Germany - use of forced emetics) or real evidence obtained by torture has to be excluded as well; indirect real evidence stemming from inhuman or degrading treatment (not torture) has to be excluded if shown that it had an impact on the defendant's conviction or sentence. Such a fully-fledged and effective exclusionary theory is missing as regards the privilege against self-incrimination and its effective protection $^{57}$ in the framework of Article $6 \mathrm{ECHR}$ and as regards Article $8 \mathrm{ECHR}$ (privacy) ${ }^{58}$, where the main guidance for the Court is fairness of the proceedings.

At the same time, admissibility of evidence is not covered by EU mutual recognition measures, although there are plans to address this topic. ${ }^{59}$ Therefore, each national court is bound by its national rules on admissibility. Unfortunately, the

United States v. Leon, 468 U. S. 897 (1984), introducing a "good faith" exception; Katz v. United States, 389 U. S. 347 (1967), overturning Olmstead v. United States, 277 U.S. 438 (1928), and introducing the theory on "reasonable expectation of privacy"; Terry v. Ohio, 392 U.S. 1 (1968), as regards the "stop and frisk" doctrine; Kyllo v. United States, 533 U.S. 27 (2001), on the use of thermal imaging devices; Kentucky v. King, No. 09-1272 (2011), as regards an expansion of warrantless searches in drug cases; etc.

55 U.S. Supreme Court, Silverthorne Lumber Co. v. United States, 251 U.S: 385 (1920), and Wong Sun v. United States, 371 U.S. 471 (1963).

${ }^{56}$ U.S. Supreme Court, Malloy v. Hogan, 378 U.S. 1 (1964), as regards the privilege against self-incrimination, Wolf v. Colorado, and Mapp v. Ohio, both mentioned above, as regards the 4th Amendment (Wolf) and exclusionary rule in the framework of the 4th Amendment (Mapp).

${ }^{57}$ In this regard, a fully-fledged, prior warning system is missing and the ECtHR has sent several mixed signals in the past. See, for example, John Murray v. UK, Application no. 18731/91, Judgment of 25 January 1996, introducing a relative approach to the right to remain silent; Jalloh v. Germany, Application no. 54810/00, Judgment of 11 July 2006, introducing "public interest" as an additional deliberation ground; O'Halloran and Francis v. UK, Application nos. 15809/02, 25624/02, Judgment of 29 June 2007, as regards an exemption for road-traffic offences, etc.

${ }^{58}$ See, for example, Schenk v. Switzerland, Application no. 10862/84, Judgment of 12 July 1988, and Khan v. UK, Application no. 35394/97, Judgment of 12 May 2000.

${ }_{59}$ European Commission, Green Paper on obtaining evidence in criminal matters from one Member State to another and securing its admissibility (COM(2009)624). See also S. Alegrezza, Critical Remarks on the Green Paper on Obtaining Evidence, Zeitschrift für Internationale Strafrechtsdogmatik, 2010, pp. 569-579. 
existing mutual recognition instruments are not clear enough on this, and often an impression is being given on the existence of mutual recognition of evidence. Furthermore, admissibility of evidence presents a kind of "mirror image" of the problems in mutual recognition, as will be illustrated on the basis of a real Slovenian-Finish cross-border case.

\section{Practical example:}

As regards admissibility of evidence (as a mirror image of the problems of mutual recognition) the Slovenian Criminal Procedural Code ${ }^{60}$ provides a fully-fledged (absolute) exclusionary rule on evidence gathered in violation of certain explicit legal provisions (on interrogations, house searches, wiretappings, covert operations, etc.) or fundamental human rights, including a fully-fledged "fruit of the poisonous tree" doctrine. At the same time, the Slovenian Supreme Court developed a formula regarding the admissibility of evidence obtained in third countries. ${ }^{61}$ According to this formula, evidence obtained abroad could be used as long as it was not violating constitutionally guaranteed human rights. The main criteria are not all the particular rules of a certain national criminal procedure but the overall picture as regards respecting basic Slovenian constitutional principles and human rights.

Recently, a highly publicised case dealing with the admissibility of evidence obtained in Finland arose in the District Court of Ljubljana. ${ }^{62}$ The case illustrates the clash of two different national systems of criminal procedure within the EU, the Finnish one giving broad prerogatives to the police authorities, without a specific legal provision to inform the suspect on the right to remain silent in an criminal investigation $^{63}$, whereby the police can by itself authorise house searches ${ }^{64}$, and the Slovenian with rules on Miranda warnings to an arrested person, as well as a suspect in general, demanding in principle an authorisation by a court for house searches, and applying a strict exclusionary rule (in principle the exclusion of all illegal evidence and the "fruits of the poisonous tree" stemming from such evidence). Despite clear provisions of the Slovenian national constitution on "Miranda" warnings and judicial authorisation of house searches, and existing ECHR case-law against Finland, the District Court admitted the evidence referring to the legality of the procedures in Finland. It applied a theory of the territorial application of the constitution, whereby some constitutional procedural rights should be limited only to the national territory, and referred to a judgment of the Slovenian Constitutional Court validating legislation on wiretappings of foreign telecommunications without a court order by the Slovenian Secret Service. ${ }^{65}$ In the author's opinion such reasoning is flawed, as it adheres to the notion of a schizophrenic constitution making the whole system of constitutional procedural safeguards fully unpredictable, despite

\footnotetext{
${ }^{60}$ Zakon o kazenskem postopku (OJ RS, n. 63/94, et seq.).

${ }^{61}$ Supreme Court of the Republic of Slovenia, I Ips 411/2006, 7 June 2007, Kp 16/2007, 30 May 2008, XI Ips 43/2010, 11 June 2010, and XI Ips 49/2010, 22 June 2010.

${ }^{62}$ District Court of Ljubljana, II K 2457/2010 (pending).

${ }^{63}$ Spronken et al. (fn. 29), Annex 3, pp. 190-205.

${ }^{64}$ The ECtHR indicated in 2011 that the Finnish system of house searches violates Article 8 ECHR - Heino v. Finland (fn. 32), and Harju v. Finland (fn. 32).

${ }^{65}$ Slovenian Constitutional Court, U-I-216/07, 4 October 2007.
} 
the fact that the criminal trial is being conducted in the territory of Slovenia where the national constitution fully applies. Following the theory of the District Court, defendants in a Slovenian criminal procedure would (at least in theory) be obliged to understand rules on admissibility of evidence of 27 national criminal procedures, as they would never be able to predict where in the EU evidence was obtained. ${ }^{66}$ Such a system would not comply with sufficient foreseeability and consequently with the rights of the defendant. ${ }^{67}$

\section{Application of stricter national constitutional standards}

As stated before, criminal procedural rights are not only rules of criminal procedural codes but also form a part of basic constitutional safeguards. As such, in Slovenia, for example, a house search has to be in principle ordered by a court ${ }^{68}$, and the role of the prosecutor is limited in principle to merely being party to the procedure (a prosecutor in Slovenia is not a quasi-court authority). ${ }^{69}$ The Slovenian general public, as well as the majority of legal professionals, do not perceive the prosecutor (as the party who tries to prove the defendant's guilt) as an independent and unbiased quasi-court authority. Therefore, in systems with such a viewpoint, any application of mutual recognition based on "judicial" decisions that are not court decisions becomes problematic. The issue already arose, for example, in the framework of the EAW giving Member States a wide margin of appreciation when naming "judicial" authorities within the EAW system. ${ }^{70}$ Such "freedom of choice" has lead to cases where even the Danish Ministry of Justice has been declared a "judicial" authority. ${ }^{71}$ Furthermore, as regards the European Evidence Warrant

\footnotetext{
${ }^{66}$ The same also applies vice versa to requests on investigation measures. See F. Zimmermann, S. Glaser and A. Motz, Mutual Recognition and its Implications for the Gathering of Evidence in Criminal proceedings: a Critical Analysis of the Initiative for a European Investigation Order, EuCLR 2011, pp. 56-80, 62 and 71-73.

${ }^{67}$ See also the ECtHR decision in Stojkovic v. France and Belgium, Application no. 25303/08, Judgment of 27 October 2011, regarding the use of statements obtained in Belgium (as the requested state) by interrogations without the presence of a lawyer, stating that it is France (as the requesting state) who has to ensure that the acts carried out in the requested state had not been in breach of the rights of the defence and thus to verify the fairness of the proceedings under its supervision (paras. 55-56).

${ }^{68}$ Article 36 of the Slovenian Constitution provides that "no one may, without a court order, enter the dwelling or other premises of another person, nor may he search the same, against the will of the resident", and further that "subject to conditions provided by law, an official may enter the dwelling or other premises of another person without a court order, and may in exceptional circumstances conduct a search in the absence of witnesses, where this is absolutely necessary for the direct apprehension of a person who has committed a criminal offence or to protect people or property". Based on such a wording the Criminal Procedural Code provides in Article 218 a precise enumeration of the exemptions.

${ }^{69}$ The Slovenian Constitutional Court described the role of public prosecutors as a sui generis function independent of the three branches of government. They belong to the judiciary in the broader sense, whereby only judges (not prosecutors) have judicial authority. Constitutional Court of the Republic of Slovenia, joined cases U-I-60/06, U-I214/06, U-I-228/06, 9 March 2007, para. 111.

${ }^{70}$ Article 6 of Framework Decision 2002/584/JHA states that "the issuing judicial authority shall be the judicial authority of the issuing Member State which is competent to issue a European arrest warrant by virtue of the law of that State". Already, in the traditional legal assistance system, national ministries of justice are often involved, but there the problem is remedied by the existence of an extensive "ordre public" refusal ground.

${ }^{71}$ Report from the Commission based on Article 34 of the Council Framework Decision of 13 June 2002 on the European arrest warrant and the surrender procedures between Member States (COM(2005)0063 (point 2.1.2); see
} 
(EEW), even investigating authorities were considered as judicial authorities, although in such cases a special validation procedure may be put in place. ${ }^{72}$

Therefore, it seems that mutual recognition could in specific cases require from Member States with a guarantistic "court-based approach" to adhere to a more "enforcement orientated approach", whereby they would have to execute measures that possibly oppose basic principles of their national constitutions, as for the moment no explicit non-recognition ground exists in that regard. Such an understanding and application of mutual recognition would be in contradiction to Article 4(2) TEU and Article 67 TFEU calling for the respect of fundamental rights and the different legal systems and traditions of the Member States, and would ignore the necessary democratic legitimacy of criminal law as a category based on historical experience and a long national process of internalisation of basic principles. ${ }^{73}$ At the same time, a kind of "schizophrenic" system would be created, whereby the same authority would have to apply two different sets of standards - one in a purely national situation and another in a cross-border situation (even if in both cases the factual basis would be identical and the defendants would be citizens of the executing state). Such a system would violate the principle of equality before the law. Therefore, such an unrestricted and unreasonable application of mutual recognition could lead to a direct clash between EU law and national constitutional law, starting once again the "solange" ${ }^{74}$ saga, and even diminishing the proper role of a judge in a democracy.

\section{The role of a judge in mutual recognition}

A judge in a classical democracy acts as a kind of corrector to the majoritarian opinion (to prevent the tyranny of the majority) ${ }^{75}$ and guarantees that the constitutional rights of the individual are fully respected. Therefore, the main characteristics of a judge should be critical thought, as he has to be capable of reasoned reflection. ${ }^{76}$ A fully automatic application of mutual recognition, in the author's opinion, carries to some extent the danger of altering this role, as the deliberation possibilities

also Council document 8302/4/09, Final report on the forth round of mutual evaluations, p. 8: "The findings of the evaluation demonstrate, however, that in some Member States non-judicial central authorities continue to play a role in cardinal aspects of the surrender procedure far beyond the administrative tasks..."

72 See Article 11(4) and (5) of Framework Decision 2008/978/JHA. The mentioned procedure solves the problem regarding investigating authorities, but does not address the issue of prosecutorial requests. In this regard, Article 12 of the mentioned Framework decision provides some guidelines (formalities and procedures should not be contrary to the fundamental principles of law of the executing State) which are, however, not reflected in the non-recognition grounds in Article 13.

${ }^{73}$ See in that regard the Lisbon Treaty judgment of the Bundesverfassungsgericht - BVerfGE 123, 267, Judgment of 30 June 2009, para. 253: "As regards the preconditions for criminal liability as well as the concepts of a fair and appropriate trial, the administration of criminal law depends on cultural processes of previous understanding that are historically grown and also determined by language, and on the alternatives which emerge in the process of deliberation which moves the respective public opinion."

${ }^{74}$ BVerfGE 37, 271, Judgment of 29 May 1974 (Solange I), and BVerfGE 73, 339, Judgment of 22 October 1986 (Solange II). See also BVerfGE 89, 155 (1993), Judgment of 12 October 1993.

${ }^{75}$ As this concept was referred to by J. S. Mill ("On Liberty") and A. de Tocqueville ("Democracy in America").

${ }^{76}$ In systems using a jury, the reasoned reflection is being guaranteed by the number of jurors. 
of a judge are being severely limited through the use of very limited grounds of non-recognition, not including human rights violations and fundamental national constitutional principles. If national legislation transposing EU law does not provide any specific clause on that, an impression could be created that a judge is prohibited from applying any additional grounds of non-recognition that are not expressively enumerated at EU level. Therefore, the danger exists that a wrong (too automatic) application of mutual recognition could create a vacuum, where nobody feels responsible.

A good example is offered by the EAW system, where a person can be apprehended for up to 90 days or more (according to Articles 17 and 23 of the EAW Framework Decision), based on EAW requests issued not only by judges but also by prosecutors and ministries of justice, and whereby the consequent court deliberation in the executing state is limited. Therefore, questions could be raised if such a system is in accordance with Article 5 ECHR, as the EAW system no longer represents a traditional extradition system (covered by Article 5(1)(f) ECHR), but could be considered as part of pre-trial detention under Article 5(1)(c) ECHR due to the following: an explicit claim that the EAW system replaced the traditional extradition system, the limitation of the classical role of a judge, and an extensive reversal of the dual criminality rule. If this were to be the case, however, the special features of Article 5(1)(c) ECHR have to be taken into account. Its application triggers the provision of Article 5(3) ECHR demanding that a person should be promptly brought before a judge or an officer authorised by law to exercise judicial power. The ECtHR gave several indications regarding the term "promptly" meaning not more than four days. ${ }^{77}$ The second issue relates to an "officer authorised by law to exercise judicial power", as several signatories of the ECHR wanted to give such a role to prosecutors, something that the ECtHR strictly opposed. ${ }^{78}$ On the other hand, it has to be acknowledged that several national courts were primarily responsible for having pointed out the existing legal lacunae within the concept of mutual recognition and highlighted the need to safeguard fundamental rights. ${ }^{79}$ As impor-

\footnotetext{
${ }^{77}$ ECtHR, Brogan and others v. UK, Application nos. 11209/84, 11234/84, 11266/84 and 11386/85, Judgment of 29 November 1988, paras. 58-60.

${ }^{78}$ ECtHR, Assenov v. Bulgaria, Application no. 24760/94, Judgment of 28 October 1998, and Moulin v. France, Application no. 37104/06, Judgment of 23 November 2010. The question came up in the Assange case (ft. 26), where the High Court stated the following (paras. 49-50): "49. Although in our view no challenge can be made to the validity of the EAW issued by the Prosecutor, it is necessary to consider whether the EAW should be accorded more intense scrutiny as a warrant issued by a party to the proceedings. That might be the case where it had not been subject to the impartial scrutiny of a judge in the Member State of issue. Although a prosecutor would ordinarily act independently in the decision to issue the EAW and in pursuance of what would in the terms of the FD be regarded as a judicial function, the decision is that of a party to the proceedings which has not been subjected to the impartial scrutiny of a judge. 50. It would therefore be entirely in conformity with the principles of mutual recognition and the promotion of mutual confidence between judges and citizens in the several Member States to recognise that circumstances can arise in respect of an EAW issued by a prosecutor... where it is necessary for a court to accord more intense scrutiny to such a warrant." See also Supreme Court of Cyprus, Igor Ovakimyan v. Attorney General of the Republic, No. 266/2005, Judgment of 19 September 2005, and Eva Karina Andersson v. Attorney-General of the Republic, No. 349/ 2008, Judgment of 6 November 2008, confirming the issuing of an EAW by Dutch and Swedish prosecutors.

${ }^{79}$ In that regard, as shown above, several constitutional courts invalidated the transposing matters on the EAW, and national courts deliberated, inter alia, on questions on the application of Article 3 ECHR, other human rights and proportionality.
} 
tant and encouraging as these decisions are, they also contribute to the further fragmentation of the existing mutual recognition system.

At the same time, the EU Charter of Fundamental Rights is now a legally binding document. As such, it has the dormant potential of further harmonisation if not even unification of fundamental rights in the sphere of criminal procedure and beyond (family status ${ }^{80}$, concept of life ${ }^{81}$ ) in the long run, creating a real lingua franca $^{82}$ Despite Article 51 of the current Charter limiting its application to EU matters and the reservations by some Member States, the Charter has the potential to introduce common standards at EU level that would also be applied to purely internal situations in the future, as was the case with the incorporation of the U.S. Bill of Rights into the federal states' legislation due to the problem of "checkerboard" laws as mentioned above. It is difficult to imagine a judge who would use two sets of fundamental principles - one for cross-border situations and another for internal situations. The question is, of course, what standards will be set at EU level, whereby the role of the Court of Justice will be essential. ${ }^{83}$ Article 52 of the Charter already provides a certain level of clear standards by referring to the ECHR and the ECtHR case-law. Such a referral to these minimum common standards, however, does not provide an answer to some substantial issues, such as an effective protection of the privilege against self-incrimination, or a coherent theory on the exclusionary rule. These topics will have to be addressed by the Court of Justice, as the role of the judiciary as the "least dangerous branch" could prove essential in cases of any possible legislative stalemate.

\section{Conclusions - A possible solution in the framework of mutual recognition}

The main challenge as regards mutual recognition is to guarantee a well-functioning and efficient system of criminal law cooperation between Member States (necessary in the case of serious forms of trans-border crime), safeguarding existing national constitutional principles, whilst at the same time maintaining the classical role of a judge. There are two basic elements that could jointly guarantee this and prevent the aforementioned anomalies. The first of these is the theory of European composite constitutionalism (Verfassungsverbund) relating to Article 4(2) TEU requiring the Union to "respect equality of Member States before the Treaties as well as

\footnotetext{
${ }^{80}$ C. Costello, Metock: Free Movement and "Normal Family Life" in the Union, Common Market Law Review 2009, pp. 587-662; M. Möstl, Preconditions and Limits of Mutual Recognition, Common Market Law Review 2010 , pp. 405-436.

${ }^{81}$ See, for example, CJEU, 4. 10. 1991, case C-159/90 (S.P. U. C. v. Grogan), [1991] ECR I-4685, as regards free movement of services and abortion; and for a comparison a similar U. S. case - Bigellow v. Virginia, 421 U. S. 809 (1975), as regards the advertising of abortion and the First Amendment.

${ }^{82}$ A. von Bogdandy, The Prospect of a European Republic: What European Citizens are Voting on, Common Market Law Review 2005, pp. 913-941, 937.

${ }^{83}$ As regards the question on the relationship between EU law and Articles 5 and 6 ECHR and the issue of proportionality, a preliminary question has been referred to the Court of Justice in case C-396/11 (Criminal proceedings against Ciprian Vasile Radu).
} 
their national identities, inherent in their fundamental structures, political and constitutional, inclusive of regional and local self-government". ${ }^{84}$ This theory highlights the co-dependency of the EU and national constitutional structures, whereby the principle of primacy of EU law is being loosened and national (constitutional) courts can invoke under very limited circumstances national constitutional limits in the face of the primacy of EU law. ${ }^{85}$

At the same time, the spirit of Article 4(2) TEU could be reflected in EU legislation on mutual recognition. First, on the chosen form of the legal acts, directives would allow more flexibility than regulations as regards accommodating these to the national constitutional framework, whereby Article 82(1) TFEU provides both possibilities. Secondly, a new non-recognition ground based on a clear and evident violation of human rights and fundamental constitutional principles could be introduced. ${ }^{86}$ In the author's opinion any fear of destruction of mutual recognition through a broad application of such a ground is exaggerated. The existing mutual legal assistance (MLA) system, based on the 1959 Council of Europe Convention $^{87}$ and the 2000 EU MLA Convention ${ }^{88}$, functions well, despite the existence of a general "ordre public" non-recognition ground. The introduction of such a "human rights violation/ fundamental constitutional principles" non-recognition ground could be accompanied by the following clarifications: - mutual recognition is a Treaty principle and, therefore, any exemptions from it should be strictly limited; - a differentiation between final court judgments and pre-trial decisions should be made; - as regards final court judgments, a strict burden of proof should lie on the convicted person, except if a violation would be clear and evident; - as regards pre-trial measures, a less strict initial burden of proof should lie on the defendant showing a possible violation or inconsistency between two systems,

\footnotetext{
${ }^{84}$ A. von Bogdandy, S. Schill, Overcoming absolute primacy: respect for national identity under the Lisbon Treaty, Common Market Law Review 2011, pp. 1417-1454.

${ }^{85}$ As regards the past relationship between German and French national constitutional/ supreme courts and the Court of Justice see, for example, M. Payandeh, Constitutional review of EU law after Honeywell: Contextualizing the relationship between the German Constitutional Court and the EU Court of Justice, Common Market Law Review 2011, pp. 9-38; and R. Mehdi, French supreme courts and EU law: Between historical compromise and accepted loyalty, Common Market Law Review 2011, pp. 439-473.

${ }^{86}$ The possibility of introducing such a non-recognition ground has been also indicated by the EU Agency for Fundamental Rights (FRA) in its EIO opinion of 14 February 2011 (ft. 22), p. 10: "A fundamental rights-based refusal ground could act as an adequate tool to prevent fundamental rights violations occurring during cross-border investigations ... a fullyfledged fundamental rights assessment in every case would not only counteract the idea of mutual recognition, but due to complex and slow procedures it might also undermine some of the fundamental standards... For this reason any establishment of a fundamental rights-based refusal ground in the directive should ideally be completed by explicit parameters. Such parameters could limit the refusal ground to circumstances where an EU Member State has a well-founded fear that the execution of an EIO would lead to a violation of fundamental rights of the individual concerned. In this way, a fundamental rights-based refusal ground could serve as a 'safetyvalve', facilitating EU Member States' compliance with fundamental rights obligations flowing from EU primary law without Member States having to deviate from EU secondary law." Such a solution has been also proposed in the draft report of the European Parliament of 16 December 2011 on the EIO (ft. 22) providing as a non-recognition ground "clear and objective evidence of an infringement of a fundamental right as laid down in the Charter of Fundamental Rights or in the ECHR or where executing a measure would clearly contradict the basic principles of national constitutions with regard to criminal proceedings" (Amendment 40).

${ }^{87}$ European Convention on Mutual Assistance in Criminal Matters of 20 April 1959, ETS No. 30, with its two additional protocols, ETS No. 99 (1978) and ETS No. 182 (2001).

${ }^{88}$ Convention on Mutual Assistance in Criminal Matters between the Member States of the European Union (OJ C 197, 12. 7. 2000, p. 1) and its additional protocol (OJ C 326, 21. 11. 2001, p. 1).
} 
except if clear and evident, whereby existing ECtHR and constitutional case-law would be an important indicator.

The introduction of such an additional ground would fully guarantee judicial prerogatives of the courts, solve the problem with the different definitions of "judicial authorities", and prevent, at the same time, the current danger of a "race to the bottom" and the implicit "amending" of national constitutions through mutual recognition (coupled with the danger of forum shopping). Instead "a walk to a reasonable top" could be achieved. Member States with a less guarantistic system would be forced to rethink their own system if they were interested in achieving cross-border cooperation, and Member States with possibly too guarantistic and extreme solutions would be forced to rethink their system if they were interested in using cross-border evidence. ${ }^{89}$ Such a framework, with a proper participation of the Court of Justice and the EU legislator as regards harmonisation based on Article 82(2) TFEU, could create, in an evolutionary way, a truly common EU legal area as regards criminal procedural law.

\footnotetext{
${ }^{89}$ For example, the Slovenian fully-fledged exclusionary rule is leading to anomalies, as it does not differentiate between the privilege against self-incrimination as a constitutional right protecting voluntariness, on the one hand, and the Miranda warning system as a prophylactic tool for the protection of such a right, on the other hand. Therefore, any violation of the Miranda warnings does not automatically entail a violation of the privilege against self-incrimination, as wrongly perceived in the Slovenian system.
} 